Table 1. BREeding System AND SEED Weight

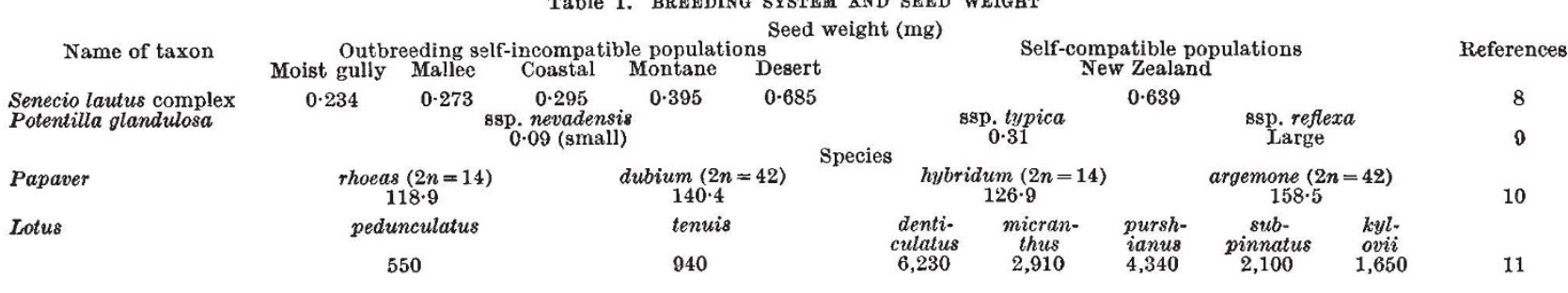

desert species to withstand unfavourable weather conditions.

I thank Professor A. S. Islam for his help.

Department of Botany,

S. I. AlI

University of Karachi,

Karachi, Pakistan.

Received December 5, 1967; revised February 26, 1968.

${ }^{2}$ Clausen, J., Keck, D. D., and Hiesey, W. M., Publ. Carneg. Inst., No. 581 (1948).

- Stebbins, G. L., Variation and Evolution in Plants (1950).

- Clausen, J., Keck, D. D., and Hiesey, W. M., Publ. Carneg. Inst., No. 520 (1940).

- Baker, H. G., Recent Adv. Bot.,1, 881 (1961).

- Lewis, D., in Reproductive Biology and Taxonomy of Vascular Plants (edit. by Hawkes, J. G.), 20 (1966).

- Ali, S. I., A ustral. J. Bot., 14, 317 (1966).

'Stebbins, G. L., Cold Spring Harbor Symp. Quant. Biol., 23, 367 (1958).

${ }^{8}$ Ali, S. I., Phyton, 13 (in the press).

- Clausen, J., Keck, D. D., and Hiesey, W. M., Publ. Carneg. Inst., No. 615 (1958).

${ }^{10}$ Harper, $Y$. L., in Reproductive Biology and Taxonomy of Vascular Plants (edit. by Hawkes, J. G.), 26 (1966).

1 Grant, W. F., Taxon, 16, 283 (1967).

\section{Budding Capacity of Undetached Begonia rex Leaves}

LEAVES of several species of plants (Begonia rex, Nautilocalyx lynchei, Endymion non-scriptus, Streptocarpus wellandii and others) have the capacity to form buds de novo but, in general, only when detached from the plant. The buds are formed at the proximal pole and often on the main leaf veins.

A few authors have observed budding on undetached leaves at the point of convergence of the leaf veins and the petiole of some varieties of Begonia rex, but the incidence is sporadic and the neoformation is subsequent to either an ablation of the terminal apex ${ }^{1}$ or to treatment with "columbine"--pigeon excrements in aqueous solutionabsorbed by the roots ${ }^{2}$.

Aqueous solutions of $6-(\gamma, \gamma$-dirnethylallylamino $)$ purine $\left(10^{-4} \mathrm{M}\right)$, a natural cytokinin existing in Corynebacterium fascians, wero sprayed once a week on undetached leaves of Begonia rex variety 'President' which were maintained

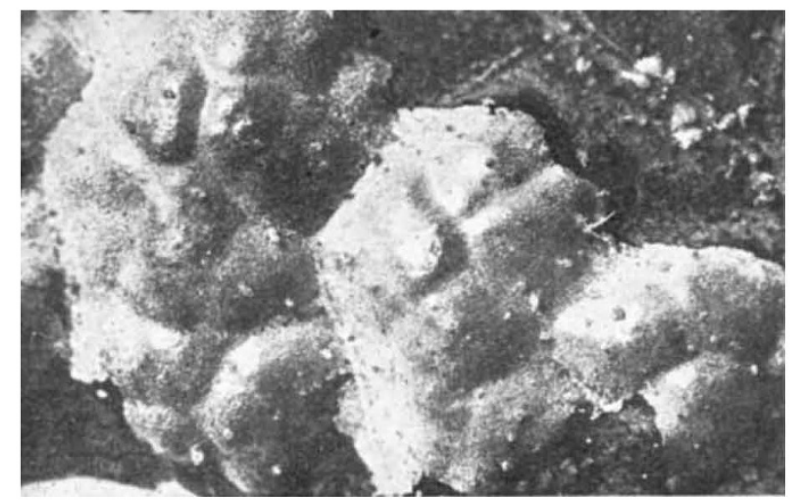

Fig. 1. Numerous small neoformed meristems on a leaf still attached to the plant. in an atmosphere of high humidity. After 5-7 weeks, tiny shoot meristems were observed over the entire leaf surface but especially on the veins (Fig. 1). This phenomenon was also seen on leaves treated in the same manner but with two cuts $1 \mathrm{~cm}$ wide made through the main vein. In this case, the neoformed buds were more numerous and more developed around the cut.

The supply of cytokinins to the whole leaf surface could cause an accumulation and retention of nutrient substances $^{3}$ and/or stimulate the synthesis of nucleic acids in epidermal cells which would bring about their dedifferentiation followed by an intense neoformation of buds. Our experiments seem to implicate a disturbance in the normal equilibrium between nutrient substances and endogenous concentrations of auxins and cytokinins leading to an enhanced capacity to bud. Heide ${ }^{4,5}$ has observed a high endogenous ratio of cytokinin to auxin in leaves of Begonia $\times$ cheimantha in conditions favourable for neoformation.

\section{Averil Chlyah-Arnason}

Laboratoire du Phytotron, Marie Tran Thanh VaN

Gif-sur-Yvette,

91 France.

Received February 28, 1968.

${ }^{2}$ Goebel, K., Flora, 94, 384 (1905).

'Prevot, P., Bull. Soc. Roy. Sci. Liège, 16, 131 (1939). ${ }^{8}$ Mothes, K., Fifth Intern. Conf. on Plant Growth Substances, 131 (Gif-sur-

- Heide, O. M., Physiol. Plant, 20, 771 (1967).

${ }^{5}$ Heide, O. M., Physiol. Plant, 20, 886 (1967).

\section{Rapid Germinability Test with Exudates from Seed}

Deterionation of seed during storage is a problem for plant breeders, seedsmen and farmers. Various methods have been proposed for testing the viability of crop seeds; these include testing enzyme activities ${ }^{1}$, the tetrazolium method ${ }^{2}$ and the $\mathrm{X}$-ray contrast method ${ }^{3}$. These are comparatively expensive, time consuming and elaborate techniques.

It is known that high temperature and humidity adversely affeot the longevity of seed. We carried out experiments with seed of rape, Brassica napus L., to find out the relationship between metabolic changes in the seed in various conditions of storage and viability. The most notable biochemical trait to distinguish dead from viable ones was found to be the exudation of sugars when soaked aseptically in distilled water. A simple method of examining the glucose in seed exudate by the use of urine sugar analysis paper will provide plant breeders and seed producers with a feasible method of testing viability. This method, based on the fact that more sugar is exuded from seed as it deteriorates, is supported by evidence from paper chromatography and the anthrone reaction.

Saccharides were extracted from seeds before and after imbibition, using 80 per cont othanol, and wore determined by paper chromatography. For imbibition, the seeds were first sterilized with 0.1 per cent 'Uspulun' and then soaked in sterile water at $30^{\circ} \mathrm{C}$ for $24 \mathrm{~h}$. The exudates in the 